\title{
The morphology and application of stem cells in digestive system surgery
}

\author{
M. Pucułek¹, J. Baj'1, P. Portincasa², M. Sitarz³ , C. Grochowski', E. Radzikowska ${ }^{4}$ \\ ${ }^{1}$ Department of Anatomy, Medical University of Lublin, Poland \\ 2Clinica Medica "A. Murri", Department of Biomedical Sciences and Human Oncology, \\ University of Bari Medical School, Bari, Italy \\ ${ }^{3}$ Department of Conservative Dentistry with Endodontics, Medical University of Lublin, Poland \\ ${ }^{4}$ Department of Plastic Surgery, Saint Elisabeth Hospital in Warsaw, Poland
}

[Received: 10 December 2019; Accepted: 23 January 2020]

\begin{abstract}
Background: Stem cells constitute a group of cells which possess the ability to self-renew as well as the capacity to differentiate into a vast number of different cells within the human organism. Moreover, stem cells are able to undergo a potentially unlimited number of divisions and this characteristic is clinically essential. Specific fields of its application include treatment of diseases mainly in the field of haematology, orthopaedics, surgery, dentistry, and neurology.

Materials and methods: In the following work, the current knowledge concerning mechanisms of stem cell treatment in different parts of the digestive system with its diseases as well as adjacent therapy for surgery has been revised.

Results: Stem cells therapy may be used in the treatment of various diseases of different parts of the digestive system. This also applies to the end part of the digestive tract (proctological diseases) because stem cells can be used to treat fistulas. Liposuction allows more recovery of mesenchymal stem cells, compared to previous bone marrow harvesting methods. Despite the application of stem cells in the treatment of different diseases used for many years so far, the therapeutic use for the regeneration of the gastrointestinal tract is still rare and unfamiliar. Conclusions: Regenerative medicine seems to be a promising tool in medical research, especially when insulated cells and designed biomaterials are taken into consideration. Major points of discussion include types of stem cells, their origin or differentiation for the treatment of many diseases. (Folia Morphol 2021; 80, 1: 13-19)
\end{abstract}

Key words: stem cell, digestive system surgery, fistula

\section{INTRODUCTION}

Stem cells constitute a group of cells able to self-renew (i.e., have the ability to undergo a potentially unlimited number of divisions). Stem cells can differentiate into other, various types of cells. These unique attributes allow stem cells to be widely used in clinical medicine in at least three fields, namely: 1) therapy to replace lost or destroyed cell lines, or to modify the behaviour of other cells; 2 ) targets of drug therapy, and 3) growth of differentiated tissue for studying disease models in vitro for drug development.

Specific areas of stem cell application allow treatment of different diseases in the field of haematology, orthopaedics, surgery, dentistry, and neurology [17]. Stem cells are used as a group of healing agents against cancer next to chemotherapy or hormone therapy (in leukaemia, lymphoma, myelodysplatic 
Table 1. Various types of stem cells

\begin{tabular}{ccccc}
\hline $\begin{array}{c}\text { Embryonic } \\
\text { stem cells }\end{array}$ & $\begin{array}{c}\text { Adult (somatic) } \\
\text { stem cells }\end{array}$ & $\begin{array}{c}\text { Induced pluripotent } \\
\text { stem cells (artificial) }\end{array}$ & $\begin{array}{c}\text { Foetal } \\
\text { stem cells }\end{array}$ & $\begin{array}{c}\text { Amniotic } \\
\text { stem cells }\end{array}$ \\
\hline Totipotent & Hematopoietic stem cells & - & Proper foetal stem cells & - \\
Pluripotent & Mesenchymal stem cells & - & Extraembryonic foetal stem cells & - \\
Multipotent & Neural stem cells & - & - & - \\
Oligopotent & Epithelial stem cells & - & - & - \\
Unipotent & Skin stem cells & - & - & - \\
\hline
\end{tabular}

syndrome and other haematopoetic cancers, as well as kidney and breast cancer or Ewing sarcoma), but they are also widely spread in aesthetic medicine [28, 43]. Moreover, stem cells constitute great potential to be applied in regenerative medicine, as well. In this context, the use of stem cells falls within an interdisciplinary area of medicine, and combines knowledge from such branches like tissue engineering and molecular biology, while supporting healing, regeneration and repair of damaged tissues.

In this review, we want to depict the current knowledge and importance of stem cell therapy in digestive system surgery.

\section{HEADING}

Cell therapy takes advantage of human cells for the regeneration of damaged tissues or even the whole organs of the patient. The major problem of transplant rejection by the recipient organism can be significantly reduced or even eliminated by creating and transplanting organs which are grown in the laboratory from patient's own stem cells. Stem cells or progenitor cells are often used because of their internal regenerative potential for damaged tissues. The presence of stem cells in transplanted tissues increases angiogenesis (vascular formation), reduces inflammation, and prevents cell death. Furthermore, stem cells secrete numerous growth factors into their surrounding environment, including vascular endothelial growth factor (VEGF), and tumour growth factor [25, 52].

There are several types of stem cells, as reported in Table 1.

Stem cells are divided into embryonic stem cells and somatic (adult) stem cells. Among the embryonic stem cells there are totipotent stem cells (derived from a multi-cell embryo) which can differentiate into cell of any type, while the pluripotent stem cells can differentiate into any type of adult cell except for placental cells (when derived from the embryonic stem cell). Adult stem cells are multipotential, which may give rise to several different types of cells, usually with similar properties (including haematopoietic cells) or unipotent cells, which may give rise to only one cell type.

Most of stem cells occur in foetal tissues and have the greatest regenerative capacity. Because of ethical reasons, stem cells used for treatment are received from adults. Mesenchymal stem cells (MCSs), which are primarily used, are isolated from almost all tissues (e.g., umbilical cord, periosteum, tendon, skin or muscle). MCSs are easily gained from adipose tissue by liposuction or by surgical excision of the tissue. This method is more effective than obtaining MCSs from bone marrow. Intensive research done by academia and industry has focused on mesenchymal stromal cells (MSCs) because of their unique features. Full use of MSCs' self-renewing ability is enabled because they can be easily isolated and expanded through in vitro culture [34].

Human MSCs derived from Wharton jelly (hWJ-hMSC) are multipotent cells which can differentiate into distinct branches of cells: osteogenic, chondrogenic, adipogenic cells, also can trans-differentiate into neural and glial cells. hWJ-hMSC line presents plasticity and has become an interesting and promising tool for the treatment of cellular and neurogenic regenerative medicine [5]. In addition, MSCs exert immunomodulatory activity and can differentiate into different lines, making them highly attractive for clinical applications in cell therapy according to the concept of developmental engineering [30]. Lenas et al. [30] studied the role of bone morphogenetic protein (BMP) signalling in the differentiation of adult mesenchymal progenitor cells, namely hMSC, towards articular cartilage. The combination of microfluidic system for screening soluble factors on three-dimensional microaggregates and synthetic compounds that selectively and specifically silenced the BMP pathway by targeting ALK2 and ALK3 receptors successfully developed a strategy effective in targeting the hMSC towards 
stable articular cartilage, both in vitro and in vivo. Thus, restricting BMP signalling can program adult hMSC to stable chondrogenesis [38].

Stem cell therapy also has an important role in heart regeneration, i.e. MSCs (also isolated from adipose tissue), cardiac cell progenitor cells (CPC) and iPSC cells [11].

Usage of stem cells in medicine begins in 1950s when James Alexander Thomson and his associates of the University of Wisconsin-Madison transplanted bone marrow in order to treat leukaemia. Stem cell surgery started in the late 1990 s by Dr. Thompson of the University of Wisconsin and researchers at Johns Hopkins University who reestablished the acquisition from human body tissues. High hopes are placed in MCS, but currently the American Society of Plastic Surgeons, World Health Organization (WHO) or other organizations do not publish official statistics on trends associated with the use of MCS in reconstructive surgery [21].

The mechanisms of action to use stem cells safely to regenerate the human body must be further explored. The United States Food and Drug Administration (FDA) in 2006 developed procedures to ensure the security of patients using stem cell therapy [26].

So far, stem cell treatment methods have been used in more than 70 diseases, including haematopoetic, cardiovascular $[16,18]$, tumour [6], metabolic [15], dermatological, immune, nervous, bone-joint, digestive, and some genetic diseases. Stem cells can be available in reconstructive surgery to replenish subcutaneous tissue defects. Applications include cancer treatment, radiotherapy, bone grafting, e.g. cranioplasty (filling of skull lid defects), filling of bone tissue defects, e.g. after resection of mandible tumours, cleft palate, treatment of chronic wounds (pressure sores, diabetic foot or as a result of ischaemia, infection), treatment of deep burns, aesthetic medicine and gastrointestinal surgery.

\section{APPLICATION OF STEM CELLS IN ENDODONTICS}

The pulp of a human tooth is composed of a basic substance and cellular components, including odontoblasts, fibroblasts and dental stem cells (DSCs), which are MSCs. DSCs include dental pulp stem cells (DPSCs), stem cells from human exfoliated deciduous teeth (SHEDs), periodontal ligament stem cells (PDLSCs), stem cells from apical papilla (SCAP), and dental follicle progenitor cells (DFPCs). DPSCs are classified as specialised (postnatal) adult stem cells, differentiated by the effects of external factors, leading to the interruption of the process of self-renewal of DSCs. DPSCs, unlike the MSCs, have a multipotential character, so they can vary to at least three different cell lines, such as osteoblasts, endothelial cells, nerve, and fat cells.

Dental pulp stem cells were first isolated in 2000 from perivascular tissue. It is essential to take into consideration the source of tissue donor cells. In general, the younger and less diverse tissue, the better conditions for obtaining DPSCs. Fully retained third molar teeth seems to be the best tissue sample to use. There are no breeding conditions at the present time that would only increase the number of DPSCs without discriminating. The characteristic properties of DPSCs allow them to be widely used in both dental and medical research as well as controlled tissue regeneration. Other options for using DPSCs include treatment of neurodegenerative diseases such as Parkinson's disease, filling bones in orthopaedics, and primarily in regenerative endodontics - regeneration of tissues in the newly emerging field of dentistry. Bone defects which are caused by malignancy, congenital deformities, traumas, osteoporosis, iatrogenic (surgical) and periodontal disease can be successfully treated using DPSCs and not only MSCs derived from bone marrow as it was in the past.

Regenerative endodontics uses stem cells to treat tooth pulp, perforation of root canal walls and bottom of the chamber, as well as necrosis of permanent teeth pulp with incomplete root formation by revascularisation and regeneration. Stem cells are an excellent source of controlled tissue regeneration. Obtaining poorly differentiated cells is difficult; however, possibilities of using DPSCs are very promising and, therefore, scientific studies in this area are still being conducted.

Stem cells are also used in therapy of different organs of digestive system. Despite using these cells for treatment of different diseases for many years, therapeutic use for the regeneration of gastrointestinal tract is still very rare and new $[19,24,33,46]$.

\section{STOMACH}

Rashed et al. [42] studied the combined effect in rat model of MSCs gained from the bone marrow and nitric oxide (NO) inducer on injured gastric mucosa. Administration of either MSCs, NO, or MSCS with NO may exert a therapeutic effect on the mucosal lesion in gastric ulcer. Effects were tested by histopathology 
after IV injection of MSCs and NO inducer. Mucosal regenerative changes and complete restoration in gastric ulcer occurred in the group receiving both stem cells and NO. Wang et al. [50] performed a study using the group of 48 clean grade male Wistar rats. The aim was to establish the model of gastric ulcer with acetic acid. Bone marrow mesenchymal stem cells (BMSCs) can accelerate ulcer healing by the secretion of VEGF, and improve the quality of ulcer cure. In the regenerative mucosa, the ulcer area, the mucosal thickness and the number of dilated glands by histology was measured by the authors. It turned out that the expression of VEGF was detected at ulcerative margin, using immunohistochemical method [50].

\section{LIVER}

In animal models, BMSC have cured animal liver fibrosis. Only few studies exist which have been performed on humans. Zhang [53] studied 60 patients with liver fibrosis secondary to hepatolenticular degeneration. The efficacy of treatment (penicillamine group vs. combination penicillamine plus BMSCs group) was evaluated based on hepatic fibrosis, liver function, and serological markers. Combination therapy was related to lower cytokine levels, meaning a significant positive effect on liver fibrosis [53].

\section{PROCTOLOGY}

Healing fistulas using stem cells is more accessible in proctology. Indeed, liposuction allows more recovery of fat cells, compared to previous bone marrow harvesting methods.

Anorectal abscesses and anal fistula are acute and chronic phase of inflammation of the anal crypt. They can also be the result of earlier abscess or rectal fistula. The causes include inflammatory bowel disease (Crohn's disease, ulcerative colitis), trauma, foreign body, radiotherapy, diseases of rectum and adjacent organs, immunosuppressive diseases and less common causes (endometriosis, radiation, tuberculosis etc.) $[12,13]$. Fistula surgeries should save sphincter muscle without inducing postoperative incontinence. Sparing treatment aimed at avoiding complications, however, is less radical, which may result in recurrences. Furthermore, operations that save sphincter muscle apply only to simple fistulas [27]. Patients with high, branched fistulas cannot be operated by traditional surgical techniques. By the stem cell procedure, the excision of walls and light of the fistula includes specially prepared cell suspension and the simultaneous stamping of the internal fistula. The cost of the extra procedure of picking and preparing the autogenous material for the slurry is certainly limited by the method. The method is effective in approximately $50 \%$ of the cases, with low invasiveness and repeatability [20]. Complications which can appear are associated with infection of the operated site and may refer to the liposuction stage and the fistula area [27]. The incontinence because of anal sphincter damage may also be a complication of surgical treatment, especially more aggressive. Several studies have been projected to elaborate minimally invasive treatment of rectovaginal and anal fistulas. The properties of adipose-derived stem cells significantly enhance a natural healing potency $[4,27,39,41,51]$.

At the beginning of $21^{\text {st }}$ century, stem cell therapy of perianal fistulas was introduced. In 2005, phase I clinical study was published, reporting the treatment of Crohn's disease witch autologous adipose tissue-derived MSCs (ADSCs) [12]. Later on the same department conducted phase II study that evidenced that fistulas treated with ADSCs showed higher healing rates $(71 \%)$ in comparison with fibrin glue treatment (16\%) [13]. However, only few ADSC-treated patients remained free of recurrence for more than 3 years in long term observation [20].

In 2012, Herreros et al. [23] performed a multicentre, randomized, single-blind, add-on clinical trial in 200 adult patients from 19 centres. Patients were randomly assigned to receive 20 million stem cells (group A, 64 patients), 20 million adipose-derived stem cells plus fibrin glue (group B, 60 patients), or fibrin glue (group C, 59 patients) after closure of the internal opening. Fistula healing was defined as reepithelisation of the external opening and absence of collection $>2 \mathrm{~cm}$ by magnetic resonance imaging. If the fistula had not healed at 12 weeks, a second dose (40 million stem cells in groups A and B) was administered. Patients were evaluated at 24 to 26 weeks (primary end point) and at 1 year (long-term follow-up). Serious adverse events were absent. In treatment of complex fistula-in-ano, a dose of 20 or 60 million adipose-derived stem cells alone or in combination with fibrin glue was a safe treatment. In the comparison of three groups no statistically significant differences were found [23].

Garcia-Olmo et al. [14] reported similar findings. They check the results of stem-cell therapy under a Compassionate-use Programme for patients with recurrent anal fistulae. There were found ten patients 
who had previously undergone multiple surgical interventions that had failed to resolve the fistula. During this research they closed the internal opening, which was followed by local implant of stem cells in the fistula-tract wall. The main cell type selected for implant was autologous expanded adipose-derived stem cells. Outcome at 8 weeks was classified as response or partial response. Evaluation 1 year after the intervention confirmed if complete healing of the fistula occurred. No adverse reactions or complications related to stem-cell therapy occurred during the study period. Both studies independently of each other proved that stem cells are safe and useful for treating anal fistulae $[14,47]$.

A recent multicentre phase III study by Panes et al. [40] showed that $50 \%$ of the patients receiving ADSC treatment had 6 months remission, compared to $34 \%$ of patients on placebo treatment. Dietz et al. [10] showed complete recovery in $83 \%$ of treated patients. A meta-analysis performed by Lightner et al. [31], which analysed severe phase I, II and III trials, reports healing rates ranging from $27-83 \%$, with positive early results in more than half of analysed studies.

\section{GASTROINTESTINAL TRACT}

Recently, results of first human phase $1 / 2$ trial using genetically modified MSCs for treatment of adenocarcinomas of the hepatobiliary and gastrointestinal tract have been published. During the progression of the tumour, MSCs are recruited into the stroma of the tumour. That process causes its growth and metastasis $[22,29,32,45]$. MSCs have several abilities, which make them perfect vehicle for tumour directed therapy. They have the ability to migrate into deep layers of the tumour microenvironment and differentiate into the tumour stroma cells. Moreover, they have low immunogenicity and can be easily isolated and multiplied $[9,36,37,44]$. The therapy was confirmed to be acceptably safe and tolerable, which was consistent with phase 1 study results [49]. One study presented signs of activity with stable disease in five of ten patients; however, no impact on tumour markers and size was observed [48].

\section{WOUNDS}

The process of wound healing involves multiple growth factors and stem cells and should be studied both in terms of research and clinical relevance. One of the surgical challenges is the problematic wound healing and ulceration in radiation-damaged tissue.
These problems may appear in non-healing surgical wounds, especially in patients with cachexia or with cancers after radiotherapy. Some ongoing clinical trials with growth factors have already produced very promising therapeutic results which can be used in earlier mentioned cases $[1-3,7,8]$.

Grafting fat tissue in an irradiated area can improve the quality of the skin and has regenerative effects. The case study by Mohan and Singh [35] describes healing of a chronic ulcer resistant to other ways of treatment using fat tissue transfer (which contains adipose-derived stem cells). A 67-year-old woman with a chronic, non-healing ulcer in her leg had a squamous cell carcinoma excised, followed by radiotherapy. After each of the multiple excisions, ulcer continued to cause symptoms. The patient underwent a wide local excision and split-thickness skin grafting. Afterwards fat was infiltrated around and under the ulcer. In the histological examination there was a post-radiation dermatitis with no evidence of malignancy. After a period in which dressings were used, a reduction in ulcer size was observed and more fat was infiltrated around the lesion. Two months later, the ulcer had been fully healed without recurrence. This case shows the potential of adipose tissue to improve damaged skin. Its use will be able to change the need for complex surgical procedures [35].

Such cases prove that modern therapies, especially cellular and protein therapies, are the future of skin treatments such as burns and chronic wounds. The increased amount of growth factors associated with inflammation, which is often seen in chronic wounds, may also carry a potential risk of cancer transformation. Cellular and humoral mechanisms of neoplasm have many similarities with physiological wound healing (stem cell involvement, inflammation, increased proliferation, similar growth factors). However, proper wound healing is strictly controlled and after it is completed, it begins a natural self-limitation process which is completely different compared to the neoplasm process $[1-3,7,8]$.

\section{SUMMARY}

One of the most promising directions in medical research is regenerative medicine, which main tools are insulated cells and specially designed biomaterials. Discussions in recent years deal with the type of stem, their origin or differentiation that will be most useful in the treatment of many diseases but there is no clear answer. However, it is obvious that different types of cells will play different roles in relation to the 
tasks they are supposed to fulfil. Bone marrow cells have been introduced into clinical practice earlier than other types of cells. The ability of mesenchymal bone marrow stem cells to differentiate into many cell types makes their use an attractive cell source for tissue and organ regeneration. However, the challenge still remains to effectively differentiate MSCs towards the desired cell lines and to maintain the phenotype of previously differentiated cells. Fully verifiable results of stem cell treatment are still growing $[1,7]$.

\section{REFERENCES}

1. Abdallah BM, Kassem M. The use of mesenchymal (skeletal) stem cells for treatment of degenerative diseases: current status and future perspectives. J Cell Physiol. 2009; 218(1): 9-12, doi: 10.1002/jcp.21572, indexed in Pubmed: 18726996.

2. Auxenfans $C$, Lequeux $C$, Perrusel E, et al. Adipose-derived stem cells (ASCs) as a source of endothelial cells in the reconstruction of endothelialized skin equivalents. J Tissue Eng Regen Med. 2012; 6(7): 512-518, doi: 10.1002/ term.454, indexed in Pubmed: 21755603.

3. Bielefeld K, Amini-Nik S, Alman B. Cutaneous wound healing: recruiting developmental pathways for regeneration. Cell Mol Life Sci. 2012; 70(12): 2059-2081, doi: 10.1007/ s00018-012-1152-9.

4. Blumetti J, Abcarian A, Quinteros F, et al. Evolution of treatment of fistula in ano. World J Surg. 2012; 36(5): 1162-1167, doi: 10.1007/s00268-012-1480-9, indexed in Pubmed: 22362043.

5. Bonilla-Porras AR, Velez-Pardo C, Jimenez-Del-Rio M. Fast transdifferentiation of human Wharton's jelly mesenchymal stem cells into neurospheres and nerve-like cells. J Neurosci Methods. 2017; 282: 52-60, doi: 10.1016/j. jneumeth.2017.03.005, indexed in Pubmed: 28286110.

6. Budny A, Grochowski C, Kozłowski P, et al. Obesity as a tumour development triggering factor. Ann Agric Environ Med. 2019; 26(1): 13-23, doi: 10.26444/aaem/100664, indexed in Pubmed: 30922023.

7. Chen Ye, Shao JZ, Xiang LX, et al. Mesenchymal stem cells: a promising candidate in regenerative medicine. Int J Biochem Cell Biol. 2008; 40(5): 815-820, doi: 10.1016/j. biocel.2008.01.007, indexed in Pubmed: 18295530.

8. Cherubino M, Rubin JP, Miljkovic N, et al. Adipose-derived stem cells for wound healing applications. Ann Plast Surg. 2011; 66(2): 210-215, doi: 10.1097/SAP. 0b013e3181e6d06c, indexed in Pubmed: 21200308.

9. Chulpanova DS, Kitaeva KV, Tazetdinova LG, et al. Application of mesenchymal stem cells for therapeutic agent delivery in anti-tumor treatment. Front Pharmacol. 2018; 9: 259, doi: 10.3389/fphar.2018.00259, indexed in Pubmed: 29615915.

10. Dietz AB, Dozois EJ, Fletcher JG, et al. Autologous mesenchymal stem cells, applied in a bioabsorbable matrix, for treatment of perianal fistulas in patients with crohn's disease. Gastroenterology. 2017; 153(1): 59-62.e2, doi: 10.1053/j. gastro.2017.04.001, indexed in Pubmed: 28400193.

11. Gapska P, Kurpisz M. Perspective in optimization of stem cell therapies for heart regeneration. Postepy
Hig Med Dosw (Online). 2017; 71(0): 975-987, doi: 10.5604/01.3001.0010.6665, indexed in Pubmed: 29225198

12. García-Olmo D, García-Arranz M, Herreros D, et al. A phase I clinical trial of the treatment of Crohn's fistula by adipose mesenchymal stem cell transplantation. Dis Colon Rectum. 2005; 48(7): 1416-1423, doi: 10.1007/s10350-005-0052-6, indexed in Pubmed: 15933795.

13. Garcia-Olmo D, Herreros D, Pascual I, et al. Expanded adipose-derived stem cells for the treatment of complex perianal fistula: a phase II clinical trial. Dis Colon Rectum. 2009; 52(1): 79-86, doi: 10.1007/DCR.0b013e3181973487, indexed in Pubmed: 19273960.

14. Garcia-Olmo D, Guadalajara H, Rubio-Perez I, et al. Recurrent anal fistulae: limited surgery supported by stem cells. World J Gastroenterol. 2015; 21 (11): 3330-3336, doi: 10.3748/wjg.v21.i11.3330, indexed in Pubmed: 25805941.

15. Grochowski C, Blicharska E, Baj J, et al. Serum iron, magnesium, copper, and manganese levels in alcoholism: a systematic review. Molecules. 2019; 24(7), doi: 10.3390/ molecules24071361, indexed in Pubmed: 30959950.

16. Grochowski C, Litak J, Kulesza B, et al. Size and location correlations with higher rupture risk of intracranial aneurysms. J Clin Neurosci. 2018; 48: 181-184, doi: 10.1016/j. jocn.2017.10.064, indexed in Pubmed: 29100674.

17. Grochowski C, Radzikowska E, Maciejewski R. Neural stem cell therapy-Brief review. Clin Neurol Neurosurg. 2018; 173: 8-14, doi: 10.1016/j.clineuro.2018.07.013, indexed in Pubmed: 30053745.

18. Grochowski C, Staśkiewicz G. Ultra high field TOF-MRA: A method to visualize small cerebral vessels. 7T TOF-MRA sequence parameters on different MRI scanners - Literature review. Neurol Neurochir Pol. 2017; 51(5): 411-418, doi: 10.1016/j.pjnns.2017.06.011, indexed in Pubmed: 28774679.

19. Gronthos S, Mankani M, Brahim J, et al. Postnatal human dental pulp stem cells (DPSCs) in vitro and in vivo. Proc Natl Acad Sci U S A. 2000; 97(25): 13625-13630, doi: 10.1073/pnas.240309797, indexed in Pubmed: 11087820.

20. Guadalajara H, Herreros D, De-La-Quintana P, et al. Long-term follow-up of patients undergoing adipose-derived adult stem cell administration to treat complex perianal fistulas. Int J Colorectal Dis. 2012; 27(5): 595-600, doi: 10.1007/s00384011-1350-1, indexed in Pubmed: 22065114.

21. Hall SS. Choroba na szalce. Świat Nauki. 2011; 236(4): 40-43.

22. Hanahan D, Coussens LM. Accessories to the crime: functions of cells recruited to the tumor microenvironment. Cancer Cell. 2012; 21(3): 309-322, doi: 10.1016/j. ccr.2012.02.022, indexed in Pubmed: 22439926.

23. Herreros MD, Garcia-Arranz M, Guadalajara $H$, et al. FATT Collaborative Group. Autologous expanded adipose-derived stem cells for the treatment of complex cryptoglandular perianal fistulas: a phase III randomized clinical trial (FATT 1: fistula Advanced Therapy Trial 1) and long-term evaluation. Dis Colon Rectum. 2012; 55(7): 762-772, doi: 10.1097/ DCR.0b013e318255364a, indexed in Pubmed: 22706128.

24. Huang GTJ, Gronthos S, Shi S. Mesenchymal stem cells derived from dental tissues vs. those from other sources: their biology and role in regenerative medicine. J Dent Res. 2009; 88(9): 792-806, doi: 10.1177/0022034509340867, indexed in Pubmed: 19767575. 
25. Hunziker R. Regenerative medicine. National Institutes of Health. 2010.

26. Kmiecik B, Skotny-Krakowian A, Rybak Z. Krótki przegląd na temat komórek macierzystych. Acta Bio-Optica et Informatica Medica. Inżynieria Biomedyczna. 2015; 21(1): 40-45.

27. Kołodziejczak M, Ciesielski P. Powikłania po leczeniu ropni i przetok odbytu. Borgis - Nowa Medycyna. 2016; 3: 114-126.

28. Koźlik M, Wójcicki P. The use of stem cells in plastic and reconstructive surgery. Adv Clin Exp Med. 2014; 23(6): 1011-1017, doi: 10.17219/acem/37360, indexed in Pubmed: 25618130.

29. LeBleu VS, Kalluri R. A peek into cancer-associated fibroblasts: origins, functions and translational impact. Dis Model Mech. 2018; 11(4), doi: 10.1242/dmm.029447, indexed in Pubmed: 29686035.

30. Lenas $P$, Moos M, Luyten FP. Developmental engineering: a new paradigm for the design and manufacturing of cell-based products. Part I: from three-dimensional cell growth to biomimetics of in vivo development. Tissue Eng Part B Rev. 2009; 15(4): 381-394, doi: 10.1089/ten. TEB.2008.0575, indexed in Pubmed: 19505199.

31. Lightner AL, Wang Z, Zubair AC, et al. A Systematic Review and Meta-analysis of Mesenchymal Stem Cell Injections for the Treatment of Perianal Crohn's Disease: Progress Made and Future Directions. Dis Colon Rectum. 2018; 61(5): 629-640, doi: 10.1097/DCR.0000000000001093, indexed in Pubmed: 29578916.

32. Lin HJ, Lin J. Seed-in-Soil: pancreatic cancer influenced by tumor microenvironment. Cancers (Basel). 2017; 9(7), doi: 10.3390/cancers9070093, indexed in Pubmed: 28753978.

33. Mackiewicz A, Lekszycki T, Olczak-Kowalczyk D. Komórki macierzyste z miazgi zęba ludzkiego (DPSCs). Charakterystyka i możliwości zastosowania - przegląd piśmiennictwa. Borgis - Nowa Stomatologia. 2014; 4: 178-182.

34. Mizukami A, Swiech K. Mesenchymal stromal cells: from discovery to manufacturing and commercialization. Stem Cells Int. 2018; 2018: 4083921, doi: 10.1155/2018/4083921, indexed in Pubmed: 30057622.

35. Mohan A, Singh S. Use of fat transfer to treat a chronic, non-healing, post-radiation ulcer: a case study. J Wound Care. 2017; 26(5): 272-273, doi: 10.12968/ jowc.2017.26.5.272, indexed in Pubmed: 28475446.

36. Moradian Tehrani R, Verdi J, Noureddini M, et al. Mesenchymal stem cells: A new platform for targeting suicide genes in cancer. J Cell Physiol. 2018; 233(5): 3831-3845, doi: 10.1002/jcp.26094, indexed in Pubmed: 28703313.

37. Niess H, Thomas MN, Schiergens TS, et al. Genetic engineering of mesenchymal stromal cells for cancer therapy: turning partners in crime into Trojan horses. Innov Surg Sci. 2016; 1(1): 19-32, doi: 10.1515/iss-2016-0005, indexed in Pubmed: 31579715.

38. Occhetta P, Pigeot S, Rasponi M, et al. Developmentally inspired programming of adult human mesenchymal stromal cells toward stable chondrogenesis. Proc Natl Acad Sci U S A. 2018; 115(18): 4625-4630, doi: 10.1073/ pnas.1720658115, indexed in Pubmed: 29666250.

39. Ortiz H, Marzo J, Ciga MA, et al. Randomized clinical trial of anal fistula plug versus endorectal advancement flap for the treatment of high cryptoglandular fistula in ano.
Br J Surg. 2009; 96(6): 608-612, doi: 10.1002/bjs.6613, indexed in Pubmed: 19402190.

40. Panés J, García-Olmo D, Assche GV, et al. Expanded allogeneic adipose-derived mesenchymal stem cells (Cx601) for complex perianal fistulas in Crohn's disease: a phase 3 randomised, double-blind controlled trial. Lancet. 2016; 388(10051): 1281-1290, doi: 10.1016/s0140-6736(16)31203-x.

41. Piejko M, Romaniszyn M, Borowczyk-Michałowska J, et al. Cell therapy in surgical treatment of fistulas. Preliminary results. Pol Przegl Chir. 2017; 89(3): 48-51, indexed in Pubmed: 28703110.

42. Rashed L, Gharib DM, Hussein RE, et al. Combined effect of bone marrow derived mesenchymal stem cells and nitric oxide inducer on injured gastric mucosa in a rat model. Tissue Cell. 2016; 48(6): 644-652, doi: 10.1016/j. tice.2016.09.006, indexed in Pubmed: 27751517.

43. Reichenberger M, Mueller W, Schäfer A, et al. Fibrin-Embedded adipose derived stem cells enhance skin flap survival. Stem Cell Rev Rep. 2012; 8(3): 844-853, doi: 10.1007/s12015-011-9341-8.

44. Rhee KJ, Lee JIn, Eom YW. Mesenchymal stem cell-mediated effects of tumor support or suppression. Int J Mol Sci. 2015; 16(12): 30015-30033, doi: 10.3390/ ijms161226215, indexed in Pubmed: 26694366.

45. Rizvi S, Khan SA, Hallemeier CL, et al. Cholangiocarcinoma - evolving concepts and therapeutic strategies. Nat Rev Clin Oncol. 2018; 15(2): 95-111, doi: 10.1038/nrclinonc.2017.157, indexed in Pubmed: 28994423.

46. Sedgley CM, Botero TM. Dental stem cells and their sources. Dent Clin North Am. 2012; 56(3): 549-561, doi: 10.1016/j. cden.2012.05.004, indexed in Pubmed: 22835537.

47. Theodoropoulos G, Mihailidou E, Kolovos G. The role of stem cells in the treatment of anal fistulas. Digestive System Diseases. 2019: 113-135, doi: 10.1007/978-3030-11965-2_7.

48. von Einem JC, Guenther C, Volk HD, et al. Treatment of advanced gastrointestinal cancer with genetically modified autologous mesenchymal stem cells: Results from the phase 1/2 TREAT-ME-1 trial. Int J Cancer. 2019; 145(6): 1538-1546, doi: 10.1002/ijc.32230, indexed in Pubmed: 30801698.

49. von Einem JC, Peter S, Günther C, et al. Treatment of advanced gastrointestinal cancer with genetically modified autologous mesenchymal stem cells - TREAT-ME-1 a phase I, first in human, first in class trial. Oncotarget. 2017; 8(46): 80156-80166, doi: 10.18632/oncotarget.20964, indexed in Pubmed: 29113291.

50. Wang G, Li C, Fan X, et al. Effect of bone marrow mesenchymal stem cells on gas-tric ulcer repairing]. Zhongguo Xiu Fu Chong Jian Wai Ke Za Zhi. 2015; 29(7): 889-892.

51. Whiteford MH. Perianal abscess/fistula disease. Clin Colon Rectal Surg. 2007; 20(2): 102-109, doi: 10.1055/s-2007977488, indexed in Pubmed: 20011384.

52. Yoshimura K, Asano Y, Aoi N, et al. Progenitor-enriched adipose tissue transplantation as rescue for breast implant complications. Breast J. 2010; 16(2): 169-175, doi: 10.1111/j.15244741.2009.00873.x, indexed in Pubmed: 19912236.

53. Zhang D. A clinical study of bone mesenchymal stem cells for the treatment of hepatic fibrosis induced by hepatolenticular degeneration. Genet Mol Res. 2017; 16(1), doi: 10.4238/gmr16019352, indexed in Pubmed: 28301671. 